\title{
In Memoriam: Susan Garretson Swartzburg (1938-1996)
}

\section{Evelyn Frangakis, Preservation Officer, National Agricultural Library}

Susan Garretson Swartzburg, 58, preservation specialist and assistant librarian for collection management at Rutgers University Libraries, passed away October 13 , 1996, from complications of pneumonia after returning from an international library association meeting in Beijing, China. A longtime member of the American Library Association, she was a pioneer in the field of library preservation. A tenured faculty member at Rutgers and an adjunct instructor and lecturer at Columbia University and Queens College in New York, Swartzburg was internationally renowned for her work in preservation. An exceptional mentor, she was much admired by her students for her depth of knowledge and devotion to the preservation of cultural property. Her untimely death is a severe loss to the preservation and conservation community.

Swartzburg held degrees from Wells College (B.A., English), New York University (M.A., English), and Simmons College (M.L.S.). Early in her profession, Swartzburg worked at Yale University (1966-72), where she planned and organized its library preservation program. Moving to Rutgers in 1972, she served as the first director of Alexander Library and later as acting art librarian for the university libraries. In 1982, she became the university's preservation librarian and earned a reputation as a dynamic motivator and facilitator. In 1990 she was named assistant librarian for collection management as well as preservation specialist.

Over the course of her career, Swartzburg wrote countless articles, col- umns, and several books, earning a reputation as a gifted and prolific writer. Her three books are significant contributions to the body of preservation literaturePreserving Library Materials: A Manual (Scarecrow, 1980; 2d ed., 1995); editor of Conservation in the Library: A Handbook of Use and Care of Traditional and Nontraditional Materials (Greenwood, 1983); and Libraries and Archives: Design and Renovation from a Preservation Perspective (Scarecrow, 1991). At the time of her death, she was involved in a collaborative effort to revise George Cunha's comprehensive preservation and conservation bibliography and was also working on a special preservation issue of Libri. She was editor of the New Jersey Library Association's Preservation Section newsletter, preservation news editor for the Mid-Atlantic Archivist, an associate editor of Conservation Administration News until 1994, and a regular columnist for Art Documentation. She served on the board of trustees for Abbey Publications, the advisory board of the Northeast Document Conservation Center, as member of the New Jersey State Librarian's Commission on Preservation and Access, on the advisory board of the New Jersey Newspaper Project, and the foundation for the Preservation of Sound Recordings.

Swartzburg was an active member of many organizations-among them ALA, the International Federation of Library Associations and Institutions, the Society of American Archivists, the American Institute for Conservation of Historic and Artistic Works, the Guild of Book Workers, the New Jersey Library Association, the 
Mid-Atlantic Regional Archives Conference, and the National Trust for Historic Preservation. She founded the Princeton Preservation Group, an active regional preservation forum. She was also instrumental in the founding of the Book Arts Center at her alma mater, Wells College.
She is survived by her husband, Dr. Marshall Swartzburg; a son, Mark; and two brothers, Edwin and Frank Garretson. Those wishing to make a contribution in her memory may contact Ron Becker at the Rutgers University Libraries Special Collections Department, (908) 932-7006.

\section{INDEX TO ADVERTISERS}

ALA

Baker \& Taylor

$2 \mathrm{~d}$ cover

Best Supply

Blackwell's

Gaylord

Kapco

$3 \mathrm{~d}$ cover

OCLC

Reed Reference

Todd Enterprises

4 th cover

University of Illinois 